\title{
The Design Path of the Employee Stock Ownership Scheme of the Conventional Holding and Mixed Ownership Enterprises
}

\author{
Wang Han*1, Huo Aimin ${ }^{2}$ \\ ${ }^{1}$ State Grid Energy Research Institute Co.,Ltd., Beijing, China \\ ${ }^{2}$ State Grid Corporation of China, Beijing, China
}

\begin{abstract}
Employee stock ownership is one of the common medium and long-term incentive methods for state-controlled mixed ownership. As the current state-controlled mixed-ownership enterprise employee shareholding is still in the pilot stage, the State-owned Assets Supervision and Administration Commission of the State Council is still relatively strict on the implementation of relevant conditions for enterprises. Based on the analysis and research on the relevant policies and corporate practices of employee stock ownership, this paper puts forward the implementation path of state-controlled mixed ownership enterprises to carry out employee stock ownership, and gives reminders and early warnings of common risks in the implementation process.
\end{abstract}

\section{INTRODUCTION}

The relevant policies on employee stock ownership in state-controlled mixed-ownership enterprises were issued much earlier than the relevant policies on equity incentives for state-controlled listed companies and equity and dividend incentives for state-owned technology enterprises. As early as the 1990s, employee stock ownership was used as a means of directional stock raising by a limited company, and its legal status was determined. In the process of evolution, the policies related to employee shareholding in state-controlled mixed-ownership enterprises have undergone several relatively large adjustments. Policies at different stages are quite different in terms of policy orientation, scope of application, and incentive targets. The nature, significance and main purpose of employee shareholding have also undergone major changes.

The operation of employee shareholding is divided into 5 steps, "determining the introduction method, determining the target, determining the quantity, determining the mechanism, and determining the exit". Compared with other medium and long-term incentive methods of state-owned enterprises, the design path steps of the employee stock ownership plan are relatively few. However, due to strict policy conditions and lack of implementation experience, state-controlled mixedownership enterprises face certain obstacles in implementing employee stockholders. In addition to meeting the strict conditions of the policy, the implementation of employee holdings also requires a comprehensive design plan that combines the company's own situation and development prospects. [1]

\section{OPERATIONAL STEPS OF EMPLOYEE STOCK HOLDING IN STATE- CONTROLLED MIXED OWNERSHIP ENTERPRISES}

\section{A. Determine How to Introduce Employee Equity}

The "Opinions on the Pilot Program of Employee Stock Ownership in State-controlled Mixed Ownership Enterprises" requires that "employee stock ownership shall be carried out mainly by means of capital increase and share expansion, and capital contribution." Generally speaking, there are three main ways to introduce employee equity.

The first is to introduce separately. State-controlled mixed-ownership enterprises separately introduce employee shareholding, that is, state-owned enterprises that have completed the mixed reform introduce employee shareholding through capital increase and share expansion

The second is the simultaneous introduction. When a wholly state-owned or wholly-owned enterprise is restructured into a state-controlled enterprise, it simultaneously introduces external investors and employee shareholding, that is, state-owned enterprises use employee shareholding as part of the shareholding reform during the mixed reform process.[2]

\section{B. Determine the Shareholders}

The "Opinions on the Pilot Program of Employee Stock Ownership in State-controlled Mixed Ownership

\footnotetext{
* Corresponding author: wanghan@sgeri.sgcc.com.cn
} 
Enterprises" clearly "support key technical positions, management positions and business positions personnel to hold shares", and set strict limits on the scope of shareholding employees.

TABLE I. SCOPE OF EMPLOYEE SHAREHOLDING IN STATE-CONTROLLED MIXED-OWNERSHIP ENTERPRISES

\begin{tabular}{|l|l|}
\hline \multicolumn{1}{|c|}{$\begin{array}{c}\text { Type of } \\
\text { Holding }\end{array}$} & \multicolumn{1}{c|}{ Personnel Scope } \\
\hline $\begin{array}{l}3 \text { types of } \\
\text { backbone } \\
\text { holdings }\end{array}$ & $\begin{array}{l}\text { Scientific research personnel, busines management } \\
\text { personnel and business backbones who work in key } \\
\text { positions and have a direct or significant impact on } \\
\text { the company's business performance and sustainable } \\
\text { development. }\end{array}$ \\
\hline & $\begin{array}{l}\text { 1. Not to hold shares without signing a labor contract } \\
\text { with the company; } \\
\text { 2. Leaders of state-owned enterprises appointed by } \\
\text { the Party Central Committee, the State Council and }\end{array}$ \\
$\begin{array}{l}\text { local party committees, governments and their } \\
\text { departments and agencies shall not hold shares; } \\
\text { situations of } \\
\text { restrict } \\
\text { shareholding }\end{array}$ & $\begin{array}{l}\text { 3. Outside directors and supervisors (including } \\
\text { employee representative supervisors) do not } \\
\text { participate in employee stock ownership; } \\
\text { 4. If there are more than one immediate family } \\
\text { members in the same enterprise, only one person can } \\
\text { hold shares.requires that the withdrawal ratio is not } \\
\text { less than 50\%) }\end{array}$ \\
\hline
\end{tabular}

The relevant policies do not explicitly limit the upper limit of the number of employees who can hold shares. However, the limitation on the scope of shareholding employees also shows that the state-owned mixedownership enterprise's employee shareholding is not a welfare and inclusive "all-employee shareholding". [3] On the one hand, from the perspective of the scope of incentives, if the company regards employee stock ownership as an incentive method, it will inevitably increase the distance between employees. Excessive number of shareholders will cause "incentive welfare" and fail to achieve the purpose of incentives. On the other hand, from the perspective of incentives, the company's shares are limited, and too many shareholders will inevitably lead to lower personal shares. This will make the shareholders neither obtain a large amount of profit, nor need to bear higher risks, and lose the significance of developing medium and long-term incentives. [4]

Therefore, the company can use positions as the division standard, and control the total number of shareholders, and comprehensively determine the scope and number of shareholders.

\section{Determine the Number of Shares}

The major prerequisite for the implementation of employee stock ownership is to ensure the controlling status of state-owned shareholders, that is, the implementation of employee stock ownership should not dilute the equity of state-owned shareholders and cause them to lose controlling rights. The "Opinions on the Pilot Program of Employee Stock Ownership by Statecontrolled Mixed Ownership Enterprises" stipulates that "the total amount of employee shares shall in principle not exceed $30 \%$ of the company's total share capital. In principle, the shareholding ratio of a single employee shall not be higher than $1 \%$ of the company's total share capital." In addition, "after the implementation of employee shareholding, the controlling status of stateowned shareholders shall be guaranteed, and their shareholding ratio shall not be less than $34 \%$ of the company's total share capital." [5]

In addition, the company can also reserve a portion of shares in advance when designing the employee shareholding plan to prepare for subsequent new management and core personnel, as well as employees who meet the requirements for holding increase due to job promotion. [6] At present, the relevant policies have not explicitly restricted or provided guidance on the management of reserved shares. Therefore, the proportion of reserved shares, grantees, grant prices, and holding methods should be determined by the company's actual conditions. Generally speaking, the proportion of reserved shares should not be too high. The award objects are mainly new recruits and promoted personnel. The grant price shall be the same as that of other grant recipients. The proxy holding method should be comprehensively considered in combination with the economics of the plan, the willingness of shareholders, the enthusiasm of investors to participate, the willingness of employees to contribute capital, and the ability to contribute capital. Finally, the company should choose a suitable holding method among major shareholders' holdings, investors' holdings, holding platforms' holdings, or existing employees' holdings. [7]

\section{Determine Employee Shareholding Mechanism}

First, the shares must be purchased by employees. The "Opinions on the Pilot Program of Employee Stock Ownership by State-controlled Mixed Ownership Enterprises" requires that "employees should make capital contributions in currency and pay in full and on time as agreed." And "pilot enterprises and state-owned shareholders shall not give shares to employees free of charge, and shall not provide financial assistance such as advances, guarantees, and loans to employees who hold shares. Employees holding shares shall not accept loans or financing assistance from other enterprises that have production and operation business dealings with the pilot enterprises." That is to say, the implementation of employee stock ownership must be funded by employees themselves, and no gift or award of shares is allowed.[8]

Second, the share price must not be lower than the actual value of the shares. The "Opinions on the Pilot Program of Employee Stock Ownership by Statecontrolled Mixed Ownership Enterprises" clearly stipulates that "the price of employee shares shall not be lower than the approved or filed net asset evaluation value per share." That is, to implement employee stock ownership, the same stock must be implemented at the same price, and the price must not be lowered to sell shares. 
Third, the holding methods can be diversified. According to the "Opinions on the Pilot Program of Employee Stock Ownership in State-controlled Mixed Ownership Enterprises," "employees who hold shares can directly hold shares in their own name, or they can hold equity through shareholding platforms such as corporate enterprises, partnership enterprises, and asset management plans." [9] All types of shareholding methods have their own advantages and disadvantages, and the company can choose a shareholding method suitable for the unit according to the actual development and incentive needs.

TABLE II. SCOPE OF EMPLOYEE SHAREHOLDING IN STATE-CONTROLLED MIXED-OWNERSHIP ENTERPRISES

\begin{tabular}{|c|c|c|c|}
\hline \multicolumn{2}{|c|}{ Category } & Advantage & Disadvantage \\
\hline $\begin{array}{l}\text { Direct } \\
\text { shareholding } \\
\text { by natural } \\
\text { persons }\end{array}$ & $\begin{array}{l}\text { Direct } \\
\text { shareholding }\end{array}$ & $\begin{array}{l}\text { As employees } \\
\text { become true } \\
\text { shareholders, they } \\
\text { can enjoy the rights } \\
\text { to participate in } \\
\text { major decision- } \\
\text { making and select } \\
\text { managers according } \\
\text { to law, and the } \\
\text { incentive effect is } \\
\text { better. }\end{array}$ & $\begin{array}{l}\text { 1. Will cause the } \\
\text { company's equity to } \\
\text { be dispersed; } \\
\text { 2. Too many } \\
\text { minority } \\
\text { shareholders may } \\
\text { affect the } \\
\text { company's decision- } \\
\text { making efficiency; } \\
\text { 3. The equity } \\
\text { transfer process is } \\
\text { complicated, which } \\
\text { is not conducive to } \\
\text { equity flow. }\end{array}$ \\
\hline \multirow{3}{*}{$\begin{array}{l}\text { Shareholding } \\
\text { platform } \\
\text { indirect } \\
\text { shareholding }\end{array}$} & $\begin{array}{l}\text { Corporate } \\
\text { shareholding }\end{array}$ & $\begin{array}{l}\text { 1. Ensure the } \\
\text { concentration of } \\
\text { company control. } \\
\text { Using the } \\
\text { shareholding } \\
\text { platform to make } \\
\text { dispersed employees } \\
\text { become a unified } \\
\text { whole is a way of } \\
\text { holding shares that } \\
\text { allows employees to } \\
\text { share profits without } \\
\text { giving up their rights. } \\
\text { 2. The procedures for } \\
\text { changing the } \\
\text { shareholding } \\
\text { structure are easier. }\end{array}$ & $\begin{array}{l}\text { Taxes are relatively } \\
\text { high and face } \\
\text { "double taxation". } \\
\text { Personal income tax } \\
\text { is levied when } \\
\text { dividends are } \\
\text { distributed, and } \\
\text { corporate income } \\
\text { tax is levied first } \\
\text { when transferring or } \\
\text { reducing shares, } \\
\text { and then personal } \\
\text { income tax is } \\
\text { levied. }\end{array}$ \\
\hline & $\begin{array}{l}\text { Partnership } \\
\text { holdings }\end{array}$ & $\begin{array}{l}\text { While possessing the } \\
\text { advantages of } \\
\text { corporate ownership, } \\
\text { the internal } \\
\text { governance } \\
\text { mechanism is more } \\
\text { flexible and taxation } \\
\text { is relatively low. }\end{array}$ & $\begin{array}{l}\text { elated policies are } \\
\text { not yet sound and } \\
\text { may face certain } \\
\text { risks. }\end{array}$ \\
\hline & $\begin{array}{l}\text { Asset } \\
\text { management } \\
\text { plan holdings }\end{array}$ & $\begin{array}{l}\text { 1. Be able to give } \\
\text { play to the } \\
\text { professional } \\
\text { advantages of } \\
\text { professional } \\
\text { institutions; } \\
\text { 2. Investment returns } \\
\text { are more stable, and } \\
\text { the risks faced by } \\
\text { enterprises are } \\
\text { relatively small. }\end{array}$ & $\begin{array}{l}\text { 1. High } \\
\text { qualification } \\
\text { requirements for } \\
\text { plan participants } \\
\text { and management } \\
\text { agencies; } \\
\text { 2. There are certain } \\
\text { management costs. }\end{array}$ \\
\hline
\end{tabular}

\section{E. Determine the Exit Mechanism of Employee Stock Ownership}

Regarding the withdrawal of employee shareholding in state-controlled mixed-ownership enterprises, the
"Opinions on the Pilot Program of Employee Stock Ownership in State-controlled Mixed Ownership Enterprises" have clear provisions. "If employees who hold shares leave the company due to resignation, transfer, retirement, death or dismissal, they shall transfer their shares internally within 12 months. For the transfer to a shareholding platform, qualified employees or shareholders of non-public capital, the transfer price shall be negotiated and determined by both parties. [10] For transfers to state-owned shareholders, the transfer price shall not be higher than the audited net asset value per share of the previous year. The transfer of shares by employees of state-controlled listed companies shall be handled in accordance with the relevant regulations of securities supervision."

\section{COMMON RISKS OF EMPLOYEE STOCK OWNERSHIP IN STATE-CONTROLLED MIXED- OWNERSHIP ENTERPRISES}

\section{A. The Shareholder Identity and Rights and Interests of the Incentive Object}

Employee stock ownership is essentially a form of equity incentive. Therefore, in terms of shareholder equity, there are the same risks as equity incentives. Employee stock ownership is essentially a form of equity incentive. Therefore, in terms of shareholder equity, there are the same risks as equity incentives. After the implementation of equity (real share) incentives and the incentive objects exercise their rights, the incentive objects hold the company's equity and have the status of company shareholders. According to Article 4 of the "Company Law of the People's Republic of China", "the shareholders of the company shall enjoy the rights of asset income, participation in major decision-making, and selection of managers in accordance with the law." Specifically, it includes inspection and reproduction rights, dividend rights and preemptive rights, voting rights, equity transfer rights, preemptive rights, etc. The voting rights of shareholders of a limited liability company may be separately stipulated in accordance with the company's articles of association. The above rights, except for voting rights which can be separately stipulated by the articles of association, belong to the inherent rights of shareholders, that is, others cannot deprive them and can only be waived by themselves. [11]

In the process of implementing equity incentives, state-owned enterprises generally hope that the shareholders' rights owned by the incentive objects should not be too large, so as to avoid risks to the normal operation of the company. According to relevant laws and regulations, combined with the practical experience of other companies, the following methods can generally be adopted to avoid related risks.

The first is that the incentive object himself signs a statement of waiving shareholder rights. In the statement, it is stated that he has renounced the shareholder status or 
rights, and it is written voluntarily rather than forced to renounce according to the wishes of others. However, this method may cause dissatisfaction among the motivated objects, thereby affecting the motivation effect. [12]

The second is to specify the conditions for shareholders with voting rights in the company's articles of association, so that the incentive objects are excluded from the scope of shareholders with voting rights. It should be noted that the articles of association of the company need to be unanimously approved by the general meeting of shareholders, so it is best to complete the amendments to the articles of association before launching equity incentives.

The third method adopts indirect shareholding, so that the incentive objects indirectly hold equity through the establishment of a limited liability company or partnership shareholding platform. However, it should be noted that indirect shareholding units must not have horizontal competition or related transactions with the enterprise. This indirect method of holding shares allows employees not to directly become shareholders of the company, but to enjoy relevant rights and interests as shareholders of the shareholding platform, which better avoids the business risks of the company. [13]

As the incentive method of employee shareholding requires employees to hold real shares, in practice, most companies will choose to hold shares indirectly through shareholding platforms to avoid the disadvantages of too many small shareholders and affecting the efficiency of company decision-making.

\section{B. The Risk of Illegal Fund-Raising on Shareholding Platforms}

When setting up an employee shareholding platform, most companies will choose a limited partnership form with simple business procedures, less restrictions, and lower taxes. [14] However, since the upper limit of the number of shareholders of a limited partnership is only 50 , some companies have achieved the goal of breaking the upper limit of the number of shareholders by setting up "nested" limited partnerships. The "nested" limited partnership enterprise refers to a limited partnership enterprise with a limited partnership enterprise as a partner.

However in the actual operation process, we must also pay attention to the upper limit of the number of shareholders. According to the "Company Law of the People's Republic of China", the number of shareholders of a joint-stock company cannot exceed 200. Although the relevant laws currently do not impose restrictions on the so-called "nested" limited partnerships, the nesting itself has violated the limit of 50 shareholders of limited partnerships. Therefore, in the operation process, it is still necessary to pay attention to the number of shareholders not too much. Especially after more than 200 people, we must be vigilant about the risk of illegal fund-raising.

\section{ConClusion}

Due to many restrictions on policy conditions, employee shareholding in state-controlled mixed-ownership enterprises does not give the implementing enterprises too much autonomy in operation. Therefore, when a statecontrolled mixed-ownership enterprise develops employee stock ownership, most of the steps can be carried out in accordance with policy regulations. [15]

In general, the operating steps of the employee stock ownership plan include "determining the introduction method, determining the object, determining the quantity, determining the mechanism, and determining the exit". Basically for each step, the policy has clear requirements.

The main risks faced by the employees of statecontrolled mixed-ownership enterprises are that they need to pay attention to that the incentive objects will also automatically have the identity and rights of shareholders, as well as the illegal fund-raising risks of the shareholding platform.

\section{Acknowledgment}

This project is supported by the State Grid Corporation of China Technology Project "Research on Talent Supply and Demand Analysis Model and Supply Strategy Research Adapting to Company Strategy" (SGSC0000KXJS2000095).

\section{REFERENCES}

1. Li, J., "Research on the Problems and Countermeasures of Employee Stock Ownership in the Process of Mixed Reform of State-owned Enterprises," in China Business Review, vol.22, Beijing, 2020, pp. 150-151.

2. Lu, J., Li, M., "On the Reform of the Socialist Employee Shareholding System with Chinese Characteristics: $1978 \sim$ 2019," in Contemporary Economic Research, vol.12, Beijing , 2019, pp. 68-75.

3. Zhao, Y., "A Brief Talk on Employee Stock Ownership Under the Reform of Mixed Ownership of State-owned Enterprises," in Chinese and Foreign Entrepreneurs, vol.17, Beijing, 2020, pp. 69-70.

4. She, X., "The Construction of State-owned Enterprise Employee Stock Ownership Incentive Mechanism Under the Background of Mixed Reform,” in Modern Business vol. 10, Beijing, 2020, pp. 53-54

5. $\quad$ Feng, L., "The Design Principles, Elements and Implementation Strategies of the Employee Stock Ownership Scheme of Statecontrolled Mixed-ownership Enterprises," in Journal of Wuhan Metallurgical Management Institute, vol. 30, Wuhan , 2020, pp. 7-9.

6. Zheng, X., "On the Employee Stock Ownership System of Chinese Enterprises," in Hebei Enterprise, vol. 12, Shijiazhuang, 2018, pp. 52-53.

7. Zhang, H., "The Choice of Employee Stock Ownership in Mixed Ownership Reform," in Railway Purchasing and Logistics, vol. 15, Beijing , 2020, pp. 28-31.

8. Zhang, M., "Research on the Implementation of Employee Stock Ownership in Mixed Ownership Enterprises," in Modern Economic Information, vol. 22, Beijing, 2019, pp. 259-260.

9. Nie, Z., "Problems in the Application of Employee Stock Ownership Plans in Chinese Enterprises and Improvement 
Measures," in Times Economics and Trade, vol. 2, Beijing, 2020 pp. 65-66.

10. Hu, S., "Review of Research on EmployeeStock Ownership," in Liaoning Economics, vol. 7, Shenyang, 2020, pp. 26-27.

11. Shao, X., "Employee Stock Ownership Plan in the Process of Deep Reform of State-owned Enterprises and Application Suggestions," in Enterprise Reform and Management, vol. 19, Beijing, 2019, pp. 18+35.

12. Wang, D., Yao, Y., "International Experience and Enlightenment of the Employee Stock Ownership System," in China Price, vol. 9, Beijing, 2020, pp. 88-91.
13. Zhang, X., Zhu, Y., Liu, X., "Typical Model and Analysis of Employee Stock Ownership System in Mixed Reform of Stateowned Enterprises," in Modern State-owned Enterprise Research, vol. 17, Beijing , 2019, pp. 28-35.

14. Zhou, H., Chen, J., "Suggestions for Improving the Employee Stock Ownership System," in Enterprise Management, vol. 12, Beijing, 2018, pp. 32-34.

15. $\mathrm{Hu}, \mathrm{T}$., Yuan, Q., "Analysis of the Legitimacy and Improvement of the Limited Partnership Employee Stock Ownership Platform," in Chinese Market, vol. 24, Beijing , 2018, pp. 9-11. 